\title{
The Interaction of Osteoblasts With Bone-Implant Materials: 1. The Effect of Physicochemical Surface Properties of Implant Materials
}

\author{
D. KUBIES ${ }^{1}$, L. HIMMLOVÁ ${ }^{2}$, T. RIEDEL ${ }^{1,3}$, E. CHÁNOVÁ ${ }^{1}$, K. BALÍK $^{5}$, \\ M. DOUDĚROVÁ ${ }^{6}$, J. BÁRTOVÁ ${ }^{2}$, V. PEŠÁKOVÁ ${ }^{4}$
}

${ }^{1}$ Institute of Macromolecular Chemistry, Academy of Sciences of the Czech Republic, Prague, Czech Republic, ${ }^{2}$ Institute of Dental Research, First Faculty of Medicine of the Charles University, Prague, Czech Republic, ${ }^{3}$ Institute of Hematology and Blood Transfusion, Prague, Czech Republic, ${ }^{4}$ Rheumatological Institute, Prague, Czech Republic, ${ }^{5}$ Institute of Rock Structure and Mechanics, Academy of Sciences of the Czech Republic, Prague, Czech Republic, ${ }^{6}$ Czech Technical University, Faculty of Mechanical Engineering, Department of Materials Engineering, Prague, Czech Republic

Received August 26, 2009

Accepted May 26, 2010

On-line October 15, 2010

\section{Summary}

This comparative study of various surface treatments of commercially available implant materials is intended as guidance for orientation among particular surface treatment methods in term of the cell reaction of normal human osteoblasts and blood coagulation. The influence of physicochemical surface parameters such as roughness, surface free energy and wettability on the response of human osteoblasts in the immediate vicinity of implants and on the blood coagulation was studied. The osteoblast proliferation was monitored and the expression of tissue mediators (TNF-a, IL-8, MMP-1, bone alkaline phosphatase, VCAM- 1 , TGF- $\beta$ ) was evaluated after the cell cultivation onto a wide range of commercially available materials (titanium and Ti6Al4V alloy with various surface treatments, CrCoMo alloy, zirconium oxide ceramics, polyethylene and carbon/carbon composite). The formation of a blood clot was investigated on the samples immersed in a freshly drawn whole rabbit blood using scanning electron microscope. The surfaces with an increased osteoblast proliferation exhibited particularly higher surface roughness (here $R_{\mathrm{a}}>3.5 \mu \mathrm{m}$ ) followed by a high polar part of the surface free energy whereas the effect of wettability played a minor role. The surface roughness was also the main factor regulating the blood coagulation. The blood clot formation analysis showed a rapid coagulum formation on the rough titanium-based surfaces. The titanium with an etching treatment was considered as the most suitable candidate for healing into the bone tissue due to high osteoblast proliferation, the highest production of osteogenesis markers and low production of inflammatory cytokines and due to the most intensive blood clot formation.

\section{Key words}

Implant - Surface properties - Proliferation - Cell number • Osteoblast $\bullet$ Cytokine $\bullet$ Surface free energy $\bullet$ Wettability $\bullet$ Blood clot formation

\section{Corresponding author}

Dana Kubies, Institute of Macromolecular Chemistry, Academy of Sciences of the Czech Republic, Heyrovsky Sq. 2, 16206 Prague 6, Czech Republic. E-mail: kubies@imc.cas.cz

\section{Introduction}

Implants replacing a missing or damaged bone or joining bone fragments together must be, contrary to implants for other purposes, not only mechanically resistant, but able to quickly heal into the host organism, i.e. bones as load-bearing structures has to fulfil their role in functioning of living organism as soon as possible (e.g. ribs as breathing apparatus, facial bones serving for 
swallowing) (Bancroft et al. 2001). From the practical point of view, a quick healing of the implant into a recipient's bone is not only a medical problem, but also has a strong socio-economic aspect. The sufficient fast osteointegration does not overload the recipient organism and put the patient back to the normal life without consecutive complications (secondary prevention) and also helps to avoid complications after surgery. The history of the implant application started with smooth polished metal implants. From that time a big part of an effort of scientists has been put on a development of surface treatments leading to acceleration of the implant osteointegration. For example, the implant osteointegration of the polished titanium has been not sufficiently fast for some of the dental clinical applications therefore the implants with very rough surfaces, and thus with a significantly enlarged surface area, leading to faster osteointegration were developed (Franchi et al. 2004). There are several surface treatments of implants on the market, especially in a dental implant area. Producers highlight the benefit, their advantages concerning a healing speed, strength of osteointegration as well as a long-term stability in the host bone (Del Fabbro et al. 2008, Marchetti et al. 2008). Nevertheless, surgeons from clinic don't choose implants according the surface treatment and, in fact, no surface is preferred in a clinical practice.

After the implant insertion into the host body, the foreign material and the living tissue always react with each other (Okumura et al. 2001). The pathway of these bilateral reactions depends on the intensity of the mechanic as well as physico-chemical irritation of cells of the affected tissue. This means that the interaction between the implant and the adjacent tissue depends not only upon bulk material properties, but in particular on the nature of the implant surface. Physico-chemical properties of the surface induce various cell responses what results also in changes in the cellular adhesion onto the implant (Eastlund et al. 1995, Jones et al. 1999). There is a lot of literature concerning the surface treatments of the particular implant materials, but we find relatively difficult to compare single studies dealing with different materials among each other due to various surface treatment methods used by authors, different sources of used cells or experimental methods.

Also another very important aspect thought not of such big interest, is the effect of the surface modification on the blood clot formation. The clotting blood is the site of the first connection between the foreign implant material and the living tissue of the recipient Park et al. 2001). The quick formation of the blood clot bonds wound together with the implant, isolates the implant bone bed from the external environment and also serves as a barrier against a possible infection. At the same time, fibrin fibres create an early connection between bone bed and the implant surface. The pluripotent cells migrate through these fibres from the bone surface to the implant and differentiate to osteoblasts.

In our previous pilot study, fibroblasts were used as model cells to observe the cell proliferation and the synthetic activity in the course of a initial contact of cells with the surface of commercially available implant materials (Pešáková et al. 2007). The comparison of behavior of fibroblasts, representing simple connective tissue cells forming substitutive tissue present at a boneimplant interface where not a tight contact is achieved, and osteoblasts, representing fully differentiated functional bone cells, can show to a possible surface treatment modality for a preferential differentiation of full-value bone cells and reduction of substitutive tissue cells.

In the present study we intend to tabularly demonstrate a main relation between the selected surface characteristics and an early osteoblast response and/or the blood clot formation and thus to facilitate the orientation in a wide range of the commercially available implant materials already in a practical use. The selected implant materials were investigated with respect to proliferation and the synthetic activity of human osteoblasts. The significant impact of physico-chemical properties of implant material surfaces on the cellular response and blood coagulation have been observed in this follow-up research.

\section{Material and Methods}

\section{Materials, surface treatments and sterilisation}

The materials of a different origin (metal, nonmetal) with various surface treatments were selected for this study. As representatives of metal materials were chosen titanium ( $\mathrm{Ti}$, polished, machined, sand-blasted, plasma-sprayed, Beznoska, Kladno, Czech Republic; or etched, Fopos, Praha, Czech Republic), Ti6Al4V alloy (Ti6Al4V, machined, Beznoska, Kladno, Czech Republic), CrCoMo alloy (CrCoMo, polished, Beznoska, Kladno, Czech Republic), stainless steel (polished, Beznoska Kladno, Czech Republic). As 
representatives of non-metal materials were selected $\mathrm{ZrO}_{2}$ ceramics $\left(\mathrm{ZrO}_{2}\right.$, fine-ground, Saint Globain, Turnov, Czech Republic), polyethylene (PE, Beznoska Kladno, Czech Republic) and carbon/carbon composite (C/C composite, Institute of Rock Structure and Mechanics AV CR, v.v.i., Prague, Czech Republic). All surface treatments of materials (polishing, sandblasting, etching, plasma-spraying) were provided by the producer. The tissue-culture-grade polystyrene (TCPS, Nunc A/S, Roskilde, Denmark) was used as a positive control in order to compare cultivation properties of the tested materials with this "gold" standard. TCPS represents a material with properties optimised for the cultivation of eukaryotic cells in vitro.

For the osteoblast cultivation, small round plates of $30 \mathrm{~mm}$ diameter and $1 \mathrm{~mm}$ thickness were used. Square plates $(20 \times 10 \times 1 \mathrm{~mm})$ were used for the measurement of the surface free energy, wettability and surface roughness. Samples were washed in deionised water and in ethanol in an ultrasonic bath and subsequently autoclaved before use for cell cultivation as well as for the characterisation of surface properties.

\section{Surface characterization}

The surface roughness of samples was measured on the Hommel tester 1000T device (Hommelwerke, Schwenningen, Germany) with a transducer for relative measurements within the scope of $100 \mu \mathrm{m}$. The track net length was $4 \mathrm{~mm}$ and three samples of each material were analysed. Each sample was measured three times in longitudinal as well as in transversal direction to the direct axis of the sample. The following basic surface characteristics were monitored: $R_{\mathrm{a}}-$ a mean arithmetic average of the profile height; $R_{\mathrm{z}}-$ an average mean profile height in five measured sections; $R_{\max }-\mathrm{a}$ maximum individual depth of roughness from the five measured sections.

The surface free energy $\gamma$ was estimated by the measurement of the static contact angle $(\theta)$ in three different solvents (water, formamide, diiodomethane) using a sessile drop method (video-camera based instrument OCA 20, Dataphysics, Filderstadt, Germany). An average value of $\theta$ obtained from the Young-Laplace fitting approach was used for calculation of the surface free energy $\gamma$ and its polar $\gamma^{\mathcal{D}}$ and disperse $\gamma$ component according to the Owen-Wendt-Rabel-Kaelble (OWRK) method (Owens 1969).

The advancing $\left(\theta_{\mathrm{A}}\right)$ and receding $\left(\theta_{\mathrm{R}}\right)$ contact angles were estimated by the dynamic Wilhelmy plate method (tensiometer Kruss K12, Hamburg, Germany) in water (Andrade et al. 1985).

The surface topography was monitored using VEGA Plus TS 5135 (Tescan s.r.o., Brno, Czech Republic) scanning electron microscope. The micrographs of tested implant materials are presented in Fig. 1.

\section{Osteoblast cultivation}

Human osteoblasts (NHOst, Cambrex Bio Science Walkersville, Inc., Walkersville, USA) were cultivated up to the $3^{\text {rd }}$ passage. The tested implant materials were put into a six-well dish (Nunc A/S, Roskilde, Denmark). Osteoblasts were inoculated on surfaces at density of $15000 / \mathrm{cm}^{2}$ and cultured in the OGM BulletKit medium (Cambrex Bio Science Walkersville, Inc., Walkersville, USA) at $37{ }^{\circ} \mathrm{C} / 5 \% \mathrm{CO}_{2}$ for 4 days The differentiation of osteoblasts was monitored using the OGM Differentiation SingleQuots set (Cambrex Bio Science Walkersville, Inc., Walkersville, USA). For further estimations, the harvested cells and the culture medium were used.

\section{Proliferation and synthetic cell activity}

The proliferation of osteoblasts was established from the mitochondrial oxidising activity of the cellular monolayer cultured on tested materials using the Laughton MTT test (Laughton 1984) after 4 days of cultivation. In parallel, the same MTT test was performed on the concentration series of osteoblasts in order to obtain a calibration curve (Laughton 1984, Mosmann 1983) and the obtained values of absorbance were embedded directly into the software program of the ELISA reader. In this way, absorbance of the tested samples was automatically re-counted for cell number per millilitre of the medium what makes possible more illuminating overview of the cell proliferation in the case of a wide range of the tested samples.

The synthetic cell activity was monitored by evaluation of the selected mediators expressed into the cultivation medium after four days of cultivation. Bone alkaline phosphatase (BAP) isoenzyme was established immunochemically by the ELISA method (Metra Biosystems, CA, USA) and the multi-potent transforming growth factor beta (TGF- $\beta$ ) by an Immunoassay Kit (BioSource International, Camarillo, USA). The levels of mediators of the immune response, i.e tumor necrosic factor alpha (TNF- $\alpha$ ) and interleukine 8 (IL-8), were established by the Immulite analyser (DPC, Los Angeles, USA). 



$\stackrel{4}{5}$

हृํ으

บे ఫ্d

政

猋疍

초

ㅇำ

ธิ

जा 웡

는

든

d

芩号

过

돈

ขิ

प⿺辶े

के 흥

눈

है ত্ำ

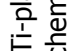

ชิ

过

逑恋

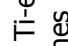

ง

矛蒡

증 항

든

$\stackrel{5}{1}+$

วิ등

ఫृ पू

등 훙

농

สิ

응

造 원

है

$+\checkmark$

흘

능

过 등

论 홍

등등 웅

항

닐

$\sum_{\text {บ } \mathbf{E}}$

岕 或

तi

宙害密 
Table 1. Selected surface roughness parameters of tested materials*.

\begin{tabular}{|c|c|c|c|c|}
\hline Material & Surface treatment & $\begin{array}{l}R_{\mathrm{a}} \\
(\mu \mathrm{m})\end{array}$ & $\begin{array}{l}R_{\mathrm{z}} \\
(\mu \mathrm{m})\end{array}$ & $\begin{array}{l}R_{\max } \\
(\mu \mathrm{m})\end{array}$ \\
\hline \multirow[t]{5}{*}{ Titanium } & polished & $0.15 \pm 0.02$ & $1.37 \pm 0.28$ & $1.98 \pm 0.49$ \\
\hline & machined & $0.60 \pm 0.14$ & $3.67 \pm 0.43$ & $4.74 \pm 0.59$ \\
\hline & sand-blasted & $3.46 \pm 0.66$ & $19.96 \pm 4.87$ & $25.15 \pm 6.39$ \\
\hline & etched & $3.54 \pm 0.06$ & $15.90 \pm 0.40$ & $20.26 \pm 0.62$ \\
\hline & plasma-sprayed & $14.51 \pm 2.74$ & $75.18 \pm 1.26$ & $96.34 \pm 3.12$ \\
\hline Ti6Al4V & machined & $0.48 \pm 0.05$ & $2.48 \pm 0.29$ & $3.13 \pm 0.50$ \\
\hline CrCoMo & polished & $0.07 \pm 0.01$ & $0.36 \pm 0.04$ & $0.49 \pm 0.04$ \\
\hline Stainless steel & polished & $0.12 \pm 0.01$ & $0.68 \pm 0.03$ & $1.10 \pm 0.04$ \\
\hline$P E$ & pressed/machined & $0.88 \pm 0.10$ & $5.54 \pm 0.28$ & $7.29 \pm 0.72$ \\
\hline $\mathrm{ZrO}_{2}$ & fine-ground & $0.23 \pm 0.02$ & $1.65 \pm 0.04$ & $1.97 \pm 0.18$ \\
\hline C/C composite & pyrolytic carbon & $2.68 \pm 0.58$ & $17.84 \pm 4.03$ & $25.05 \pm 4.14$ \\
\hline
\end{tabular}

$*$ data presented as mean \pm S.D.

Table 2. The surface free energy of selected tested samples*.

\begin{tabular}{|c|c|c|c|}
\hline Surface & $\begin{array}{l}\gamma^{\mathrm{p}} \\
(\mathrm{mN} / \mathrm{m})\end{array}$ & $\begin{array}{l}\gamma^{\mathrm{d}} \\
(\mathrm{mN} / \mathrm{m})\end{array}$ & $\begin{array}{l}\gamma \\
(\mathrm{mN} / \mathrm{m})\end{array}$ \\
\hline TCPS & $27.06 \pm 1.11$ & $43.15 \pm 2.53$ & $70.21 \pm 1.92$ \\
\hline Ti-polished & $15.97 \pm 0.54$ & $31.05 \pm 0.98$ & $47.01 \pm 1.54$ \\
\hline Ti-etched & $8.88 \pm 2.51$ & $32.97 \pm 2.11$ & $41.85 \pm 4.41$ \\
\hline Ti6Al4V & $8.59 \pm 5.31$ & $30.14 \pm 11$ & $38.73 \pm 6.01$ \\
\hline $\mathrm{ZrO}_{2}$ & $7.55 \pm 1.08$ & $34.46 \pm 1.53$ & $42.01 \pm 1.91$ \\
\hline Stainless steel & $4.47 \pm 0.12$ & $29.61 \pm 0.83$ & $34.08 \pm 0.84$ \\
\hline CrCoMo & $2.46 \pm 0.51$ & $31.18 \pm 0.95$ & $33.74 \pm 1.05$ \\
\hline$P E$ & $0.39 \pm 0.02$ & $35.31 \pm 1.08$ & $35.70 \pm 1.52$ \\
\hline C/C composite & $0.12 \pm 0.03$ & $46.96 \pm 1.57$ & $47.08 \pm 1.93$ \\
\hline
\end{tabular}

* data presented as mean \pm S.D.

The evaluation of the expressed adhesive vascular cell adhesion molecule 1 (VCAM-1) was done using the "sandwich" enzyme-immuno-sorbent analysis with a commercially available kit (Bender, MedSystems, Vienna, Austria); the MMP-1 metalloproteinase levels were established using the enzyme immuno-sorbent analysis kits (NOVITEC, Vienna, Austria).

\section{Blood clot coagulation analysis}

The qualitative analysis of the blood clot formation was carried out on all tested samples after 2, 3, 4 and 5 minutes incubation of the surfaces with blood. For a quantitative analysis, the incubation time of materials with blood was set down for 4 minutes and analysis was performed for Ti-polished, Ti-etched, Tiplasma-sprayed, $\mathrm{ZrO}_{2}$ ceramics and stainless steel samples.

The samples were put into a 24 -well dish (Nunc A/S, Roskilde, Denmark) under sterile conditions. The wells were infused with $3 \mathrm{ml}$ of a freshly drawn whole rabbit blood, covered with a lid and left standing. After the selected incubation time, the samples were taken out, rinsed in a saline solution, fixed in glutaraldehyde, dried and coated with gold. Afterwards, the samples were investigated by scanning electron microscopy (JSM 5500 LV, Tokyo, Japan) (Steinberg et al. 1992). The surfaces were analysed using magnification 800 in meander-like patterns because of the sample size. Each side of the 


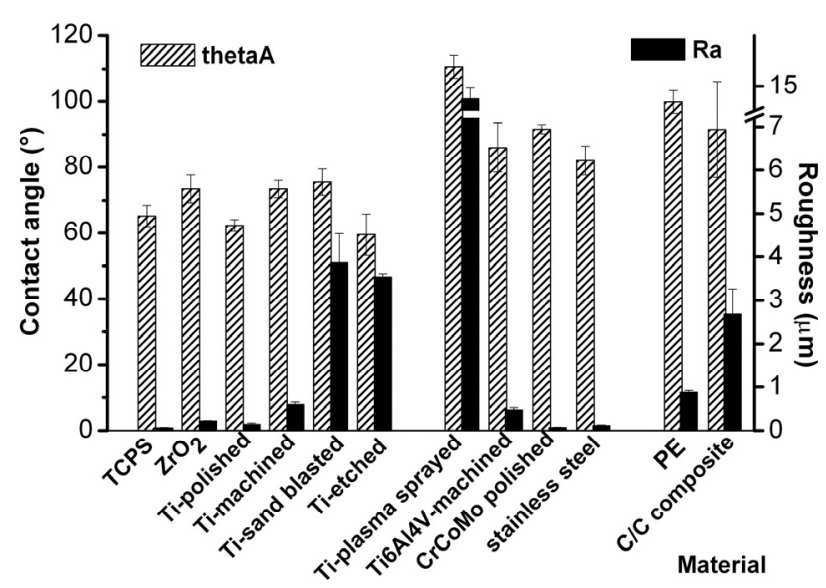

Fig. 2. The wettability (四) and the surface roughness ( $\boldsymbol{\square}$ ) of tested implant materials.

sample surface was divided into 16 fields to better describe the clot formation on whole sample surface. The numbers of elements adhered onto the surface, clusters formed by the element aggregation, created fibres and/or developed meshes were statistically evaluated.

\section{Statistical evaluation}

The MTT-test for proliferation assay was repeated twice, always with four parallel samples for each surface type. The determination of tissue mediators was done as follows: The cultivation medium from 4 parallel samples of each tested surface was pooled. Then, the ELISA analysis was done using the pooled samples from two separated cultivations, always with two parallel assays using one ELISA kit. Therefore, the statistical analysis of obtained data was not performed. For the evaluation of the surface free energy $(\gamma), 5$ plates of each material were used for particular measurements; every sample was characterised by 6 drops for individual solvents. Five parallel samples of each material were used for all measurements of the dynamic contact angles. Two parallel samples of each material were used for the evaluation of the surface roughness; the measured values were processed using basic statistical tools. The blood clot formation was evaluated using 3 samples of each material and 16 fields on each sample side were viewed and analyzed using KruskalWallis and Mann-Whitney test.

\section{Results}

Roughness, surface free energy and wettability of implant materials

The selected parameters of the surface roughness, namely $R_{\mathrm{a}}, R_{\mathrm{z}}$ and $R_{\max }$, are presented in Table 1. Based on

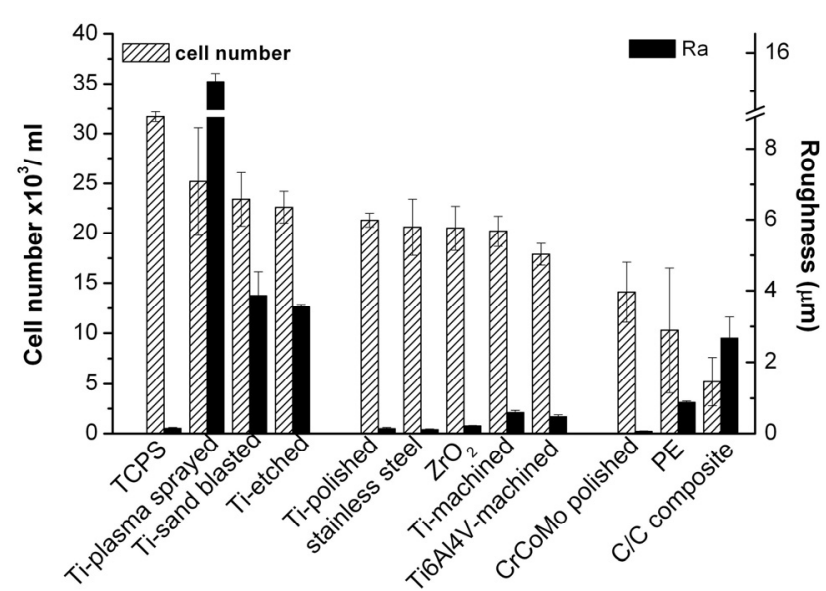

Fig. 3. Cell number expressed as a number of osteoblasts attached to the surface (四) after four days of the cultivation compared to the surface roughness ( $\boldsymbol{\square})$. Osteoblasts were inoculated on the surfaces at density of $15000 / \mathrm{cm}^{2}$. The tested materials are aligned on the $x$-axis according to the decreasing cell number.

the main monitored parameter $R_{\mathrm{a}}$, the surfaces were divided to surfaces with the polishing, the ablation (i.e. machining, sand-blasting, etching) and the deposition (i.e. plasma-spraying of titanium) surface treatment.

The polished materials (titanium, CrCoMo alloy, stainless steel) and the gently machined $\mathrm{ZrO}_{2}$ ceramics represent homogeneous surfaces of $R_{\mathrm{a}}$ ranged from 0.07 to $0.225 \mu \mathrm{m}$ and standard deviation of $10 \%$, what is a value usually observed for surfaces prepared by this surface treatment (Ponsonnet et al. 2003). The $R_{\mathrm{a}}$ of the surfaces with the ablation treatment ranges from 0.48 to $3.54 \mu \mathrm{m}$ with the standard deviation among $10-20 \%$. The sand-blasting led to the increased surface inhomogeneity probably due to a different extent of abrasion in the course of individual treatment cycles. In contrast, the etching provided a relatively homogeneous surface as a result of a constant composition of the etching solution during the treatment. The plasma-deposition of an upper titanium layer onto titanium resulted into an inhomogenous surface with the highest roughness of $R_{\mathrm{a}}=14.5 \mu \mathrm{m}$. The $\mathrm{C} / \mathrm{C}$ composite (Pešáková et al. 2000) represents also a highly inhomogeneous surface with the standard deviation of $R_{\mathrm{a}}$ overpassing $20 \%$ as a result of the used modification.

The surface free energy $(\gamma)$ and its disperse $\left(\gamma^{\mathrm{d}}\right)$ and polar $\left(\gamma^{\mathrm{p}}\right)$ components were determined for the surfaces with low roughness. The results are presented in Table 2 where materials are ordered according to the decreasing $\gamma^{\mathrm{p}}$. The values of $\gamma$ ranged among 33.74 and $47.08 \mathrm{mN} / \mathrm{m}$; the highest $\gamma$ was determined for titanium $(47.01 \mathrm{mN} / \mathrm{m})$ and $\mathrm{C} / \mathrm{C}$ composite $(47.08 \mathrm{mN} / \mathrm{m})$. The $\gamma^{\mathrm{d}}$ 
was considered very similar for all tested materials (except $\mathrm{C} / \mathrm{C}$ composite) whereas the significant differences were observed for $\gamma^{\mathrm{p}}$, which is considered as an important factor affecting biological interactions. The highest $\gamma^{\mathrm{p}}$ was determined for the polished titanium, followed by $\mathrm{ZrO}_{2}$ ceramics, stainless steel and $\mathrm{CrCoMo}$ alloy whereas $\gamma^{\mathrm{p}}$ of non-metal surfaces $\mathrm{PE}$ and $\mathrm{C} / \mathrm{C}$ composite approximated to zero.

The surface wettability was measured by a dynamic Wilhelmy plate method which allows calculation of average values of contact angles during the sample immersing into and withdrawing from a liquid across the whole surface. This method allows minimize the impact of the surface roughness on contact angles what often occurs when optical methods are used. All measurements were performed on the samples after autoclaving since it is known that sterilization processes can significantly affect the surface properties. Indeed, autoclaving led to the increase in contact angles approximately for 7 degree in our study (data not presented) what is consistent with the findings of Pegueroles et al. (2008). In the sake of clarity, only the advancing contact angle $\theta_{\mathrm{A}}$ (Fig. 2), generally considered as an overall parameter of wettability, is discussed in the present work. More detail discussion about both advancing and receding contact angles is presented in our previous work (Pešáková et al. 2007).

Based on wettability (Fig. 2), the materials were divided into following groups: the surfaces with a moderate hydrophilicity, the hydrophobic metal surfaces and the hydrophobic non-metal surfaces. Ti-based materials and $\mathrm{ZrO}_{2}$ ceramics with $R_{\mathrm{a}}<4 \mu \mathrm{m}$ exhibit the average contact angle $\theta_{\mathrm{A}}$ below $70^{\circ}$. This relatively moderated $\theta_{\mathrm{A}}$ results from the presence of oxides of titanium or zirconium at the upper layer. The highest observed wettability of the Ti-etched surface is caused by the presence of the upper hydrated $\mathrm{TiO}_{2}$ layer formed during the surface treatment by the hydrochloric acid/ hydrofluoric acid mixture.

The metal alloys $\left(\theta_{\mathrm{A}}\right.$ upper $\left.80^{\circ}\right)$ and the Tiplasma-sprayed surface $\left(\theta_{A}=108^{\circ}\right)$ represent metal hydrophobic surfaces. An observed low wettability of Tiplasma-sprayed in comparison with other Ti-based surfaces is a result of the high surface roughness (Table 1). On the other hand, higher $\theta_{\mathrm{A}}$ of the machined Ti6Al4V surface $\left(\theta_{\mathrm{A}}=83^{\circ}\right)$ than that of the neat machined Ti $\left(\theta_{\mathrm{A}}=73^{\circ}\right)$ is caused probably by the addition of alloying elements into titanium, and hence a different representation of oxides on the sample surface. Finally, non-metal surfaces are characterized by $\theta_{\mathrm{A}}$ over $90^{\circ}$; no significant effect of the surface roughness on wettability was observed in this group.

\section{Proliferation of osteoblasts on implant materials}

The number of proliferating cells after four-day cultivation was determined following the cell mitochondrial activity. Fig. 3 shows the tested surfaces ordered by a decreasing cell number together with the corresponding surface roughness $\left(R_{\mathrm{a}}\right)$.

No distinct differences in proliferation were found among the most of the particular surfaces; however, based on the cell number, tested surfaces were divided into three groups. The osteoblasts proliferated best on the control TCPS and Ti-based materials (the first group of materials). These surfaces also exhibited the highest surface roughness exceeding $3 \mu \mathrm{m}$ in this study and $\gamma^{\mathrm{p}}$ higher than $8.88 \mathrm{mN} / \mathrm{m}$ (Table 2). The second group of materials with lower proliferation includes metal materials and $\mathrm{ZrO}_{2}$ ceramics treated with polishing or machining and the surface roughness below $1 \mu \mathrm{m}$. Besides Ti-polished, the values of $\gamma^{\mathrm{P}}$ ranged from 2.5 to $7.55 \mathrm{mN} / \mathrm{m}$ in this group. The least suitable surfaces for osteoblasts cultivation are surfaces included in the third group, namely the CrCoMo alloy of $\gamma^{\mathrm{P}}=2.46 \mathrm{mN} / \mathrm{m}$ and non-metal materials $\mathrm{PE}$ and $\mathrm{C} / \mathrm{C}$ composite with very low values of the polar component $\gamma^{\mathrm{P}}$ nearing zero.

\section{Metabolic activity of osteoblasts}

The levels of selected tissue mediators expressed by cells were determined from the cultivation medium after four days of the cultivation. Three types of the cellular synthesis were characterised: a) the osteoblast activity (BAP and TGF- $\beta$ assays), b) the production of metalloproteinase collagenase 1 (MMP-1), and c) inflammatory mediators (TNF- $\alpha$, IL- 8 , soluble VCAM-1). The results are presented in the charts (Figs 47), where tested materials are ordered on the $\mathrm{x}$ axis according to the decreasing proliferation as shown in Fig. 3.

\section{Synthetic activity of osteoblasts and MMP-1production}

The production of BAP and TGF- $\beta$ are shown in

Fig. 4 and Fig. 5. There was an obvious tendency towards an increased expression of both markers with decreasing proliferation. The lowest BAP and TGF- $\beta$ production was detected on the TCPS control and on Ti-plasma-sprayed. Concerning the group with the highest proliferation (Fig. 3), the Ti-etched surface initiated the highest 


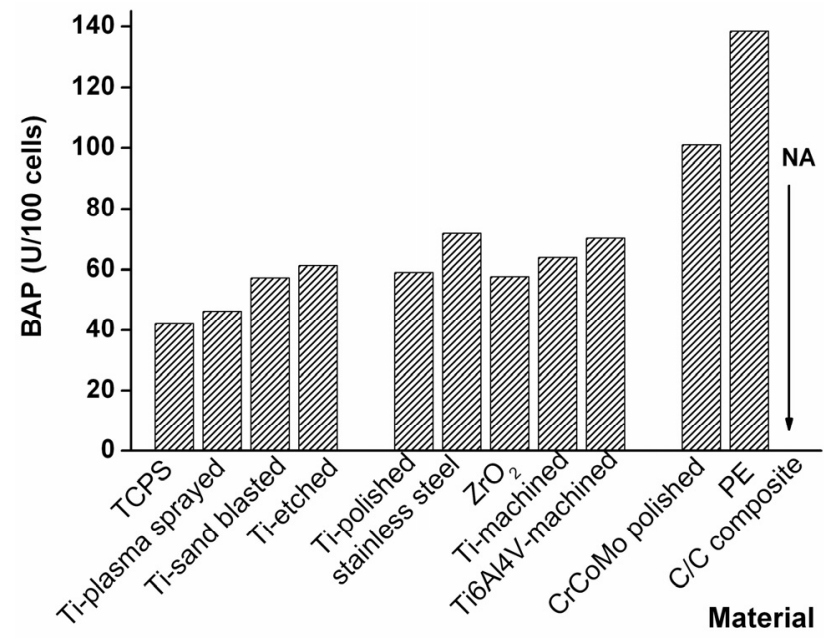

Fig. 4. Production of BAP by osteoblasts on tested surfaces after four days of the cultivation. The materials are aligned on $\mathrm{x}$-axis according to the decreasing cell number. NA - not analyzed, under detection limit of the used method. Osteoblasts were inoculated on the surfaces at density of $15000 / \mathrm{cm}^{2}$.

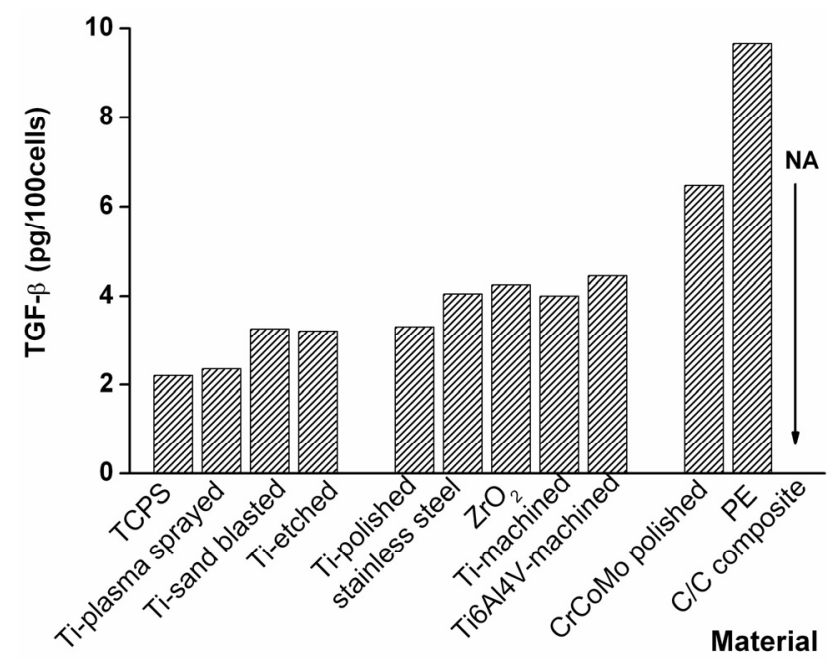

Fig. 5. Production of TGF- $\beta$ by osteoblasts on tested surfaces after four days of the cultivation. The materials are aligned on $x$-axis according to the decreasing cell number. NA - not analyzed, under detection limit of the used method. Osteoblasts were inoculated on the surfaces at density of $15000 / \mathrm{cm}^{2}$.

production of osteoblast activity markers. The surfaces with low proliferation, i.e. CrCoMo alloy and PE, exhibited several times higher levels of both markers than TCPS. In the case of the $\mathrm{C} / \mathrm{C}$ composite, the measured values of BAP and TGF- $\beta$ did not reach a lower detection limit of the used method.

The expression of the metalloproteinase MMP-1 is depicted in Fig. 6. The MMP-1 production on the Tibased surfaces with the highest proliferation (Ti-plasmasprayed, Ti sand-blasted) is lower than on the TCPS control whereas osteoblasts on all non-metal materials (i.e. $\mathrm{ZrO}_{2}, \mathrm{PE}$ and $\mathrm{C} / \mathrm{C}$ composite) produced significantly

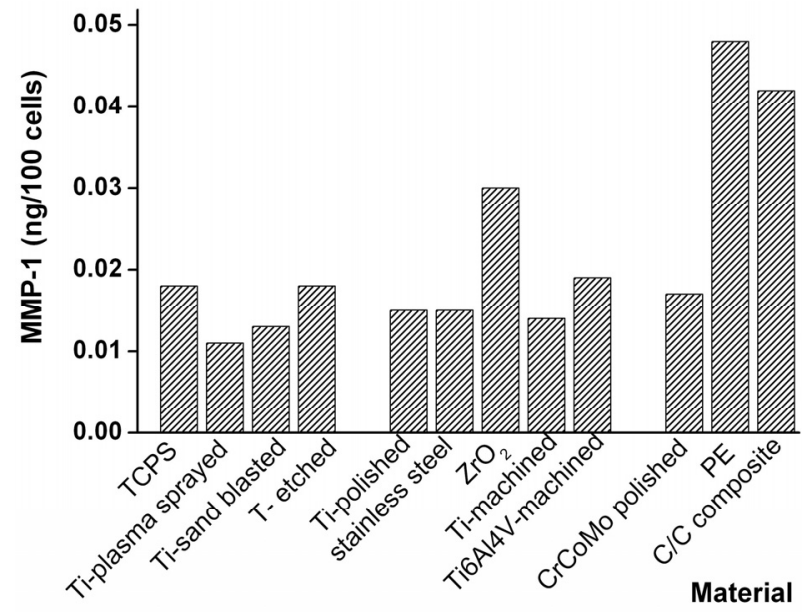

Fig. 6. Production of MMP-1 by osteoblasts on tested surfaces after four days of the cultivation. The materials are aligned on $\mathrm{x}$-axis according to the decreasing cell number. Osteoblasts were inoculated on the surfaces at density of $15000 / \mathrm{cm}^{2}$.

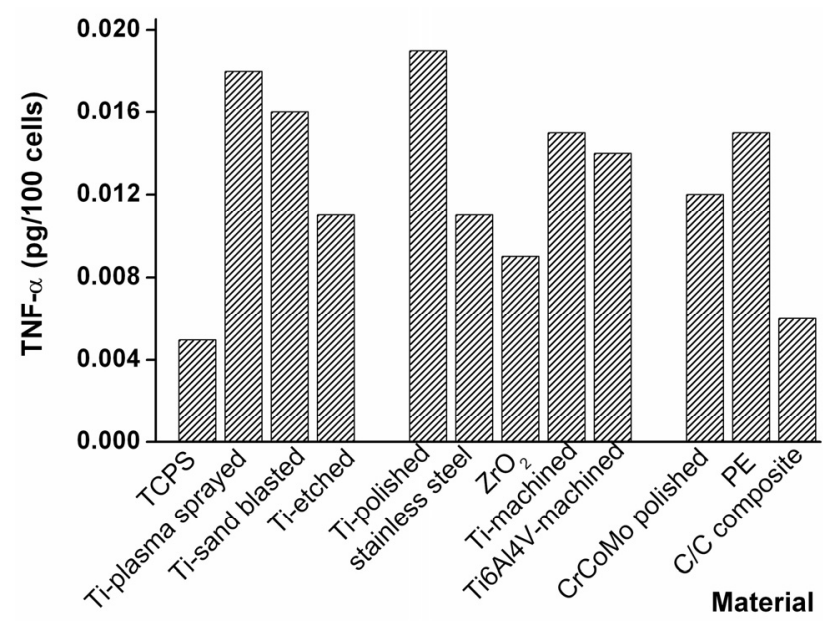

Fig. 7. Production of TNF- $\alpha$ by osteoblasts on tested surfaces after four days of the cultivation. The materials are aligned on $x$-axis according to the decreasing cell number. Osteoblasts were inoculated on the surfaces at density of $15000 / \mathrm{cm}^{2}$.

more MMP-1 than on TCPS. Again, the low proliferation was accompanied by the increased production of metalloproteinase.

\section{Expression of markers of inflammatory response}

The expression of tumor necrosic factor-alpha (TNF- $\alpha$ ) is shown on Fig. 7. The TNF- $\alpha$ production on all studied materials significantly exceeded the TCPS control what we found consistent with the fact that TCPS is the material specially developed for the best cell viability. It is also evident that the TNF- $\alpha$ expression on the samples of a high proliferation depends primarily upon the material origin in our study. Surprisingly, the highest TNF- $\alpha$ value were observed on all Ti-based materials, i.e. Ti-polished, Ti-plasma-sprayed, Ti-sand-blasted, 


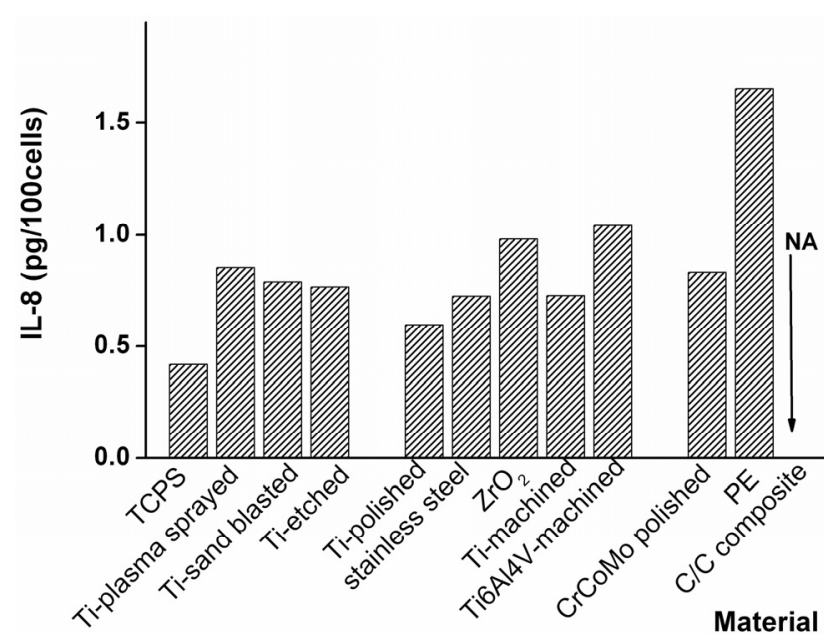

Fig. 8. Production of IL-8 by osteoblasts on tested surfaces after four days of the cultivation. The materials are aligned on $x$-axis according to the decreasing cell number. NA - not analyzed, under detection limit of the used method. Osteoblasts were inoculated on the surfaces at density of $15000 / \mathrm{cm}^{2}$.

Ti-machined and Ti6Al4V-machined. A lower TNF- $\alpha$ production was observed on Ti-etched, where the chemical composition of the surface was altered by etching, and on $\mathrm{ZrO}_{2}$ ceramics. The low TNF- $\alpha$ value comparable with TCPS were detected for $\mathrm{C} / \mathrm{C}$ composite, what is in contrast to the TNF- $\alpha$ production on $\mathrm{C} / \mathrm{C}$ composite by fibroblasts (Pešáková et al. 2007).

The next determined markers were the inflammatory chemokine interleukine 8 (IL-8) (Fritz et al. 2002) and the soluble human vascular cell adhesion molecule 1 (VCAM-1) attracting leukocytes to damaged tissue, both expressed by cells into the cultivation media (Sinha et al. 1996). The production of IL-8 (Fig. 8) on all materials was a relatively equable and higher than on TCPS. The effect of the surface treatment was not obvious for osteoblasts in the contrast to fibroblasts where a significantly higher IL-8 production on non-metal surfaces was observed (Pešáková et al. 2007). The production of VCAM-1 oscillated around the TCPS control (Fig. 9). Apparently, more pronounced increase in the VCAM-1 production was mediated also by low surface roughness on Tipolished, stainless steel and/or CrCoMo alloy. For both markers, the measured IL-8 and VCAM-1 values on PE and $\mathrm{C} / \mathrm{C}$ composite were under a lower detection limit of the used analytical method, what could have reflected a low number of proliferating cells detected on these two surfaces.

\section{Blood clot formation analysis}

The qualitative description of the blood clot

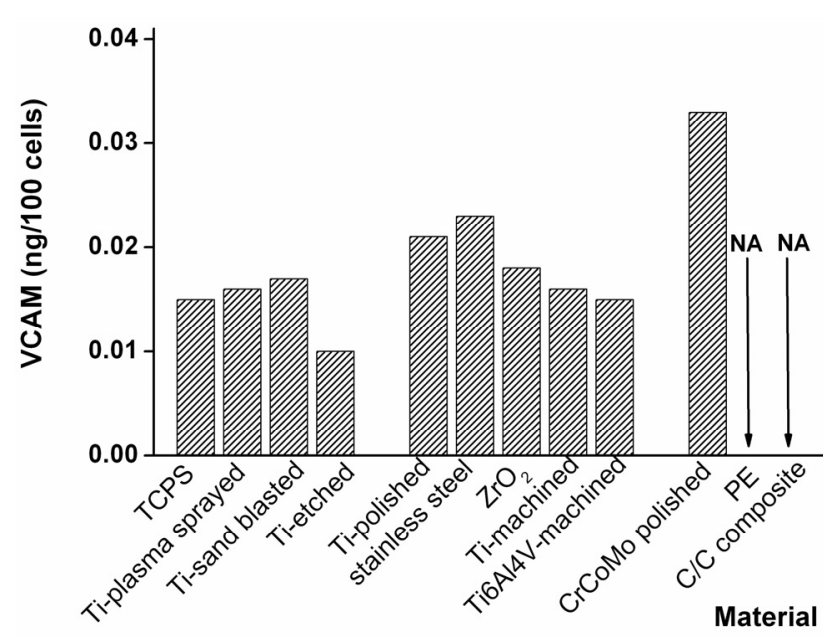

Fig. 9. Production of VCAM-1 by osteoblasts on tested surfaces after four days of the cultivation. The materials are aligned on $x$-axis according to the decreasing cell number. NA - not analyzed, under detection limit of the used method. Osteoblasts were inoculated on the surfaces at density of $15000 / \mathrm{cm}^{2}$.

development on the implant surface with a prolonging incubation $(2,3,4$ and $5 \mathrm{~min})$ with a rabbit blood is presented in Table 3. The tested surfaces are listed according to the speed of the blood clot formation. The following categories were evaluated: adhered blood elements, clusters formed due to the element aggregation, formed fibrin fibres and/or developed meshes. The category dominating on the particular surface in the selected minute of incubation is noted in Table 3.

The most rapid blood clot formation was observed on Ti-plasma-sprayed and on non-metal $\mathrm{C} / \mathrm{C}$ composite and PE samples, where some clusters were already formed in the $2^{\text {nd }}$ minute. The blood agglutinated with a similar rate and with the same dominant category in time intervals on all Ti-based surfaces. The slowest blood clot formation was observed on smooth samples of CrCoMo alloy, stainless steel, $\mathrm{ZrO}_{2}$ ceramics and TCPS. Blood elements adhered onto TCPS and $\mathrm{ZrO}_{2}$ ceramics were mostly round-shape with no signs of the platelet activation (Fig. 10a).

A more detail quantitative analysis of the developed blood clot was performed for Ti-polished, Tietched, Ti-plasma-sprayed, $\mathrm{ZrO}_{2}$ ceramics and stainless steel. The analysis was carried out after 4 minutes of the sample incubation with the rabbit blood. The same categories of the blood clot formation, as analysed for the qualitative analysis, were determined. Results are presented in Table 4. Generally, the observed high standard deviation was a result of an inhomogeneous distribution of the investigated parameters on the surfaces. 


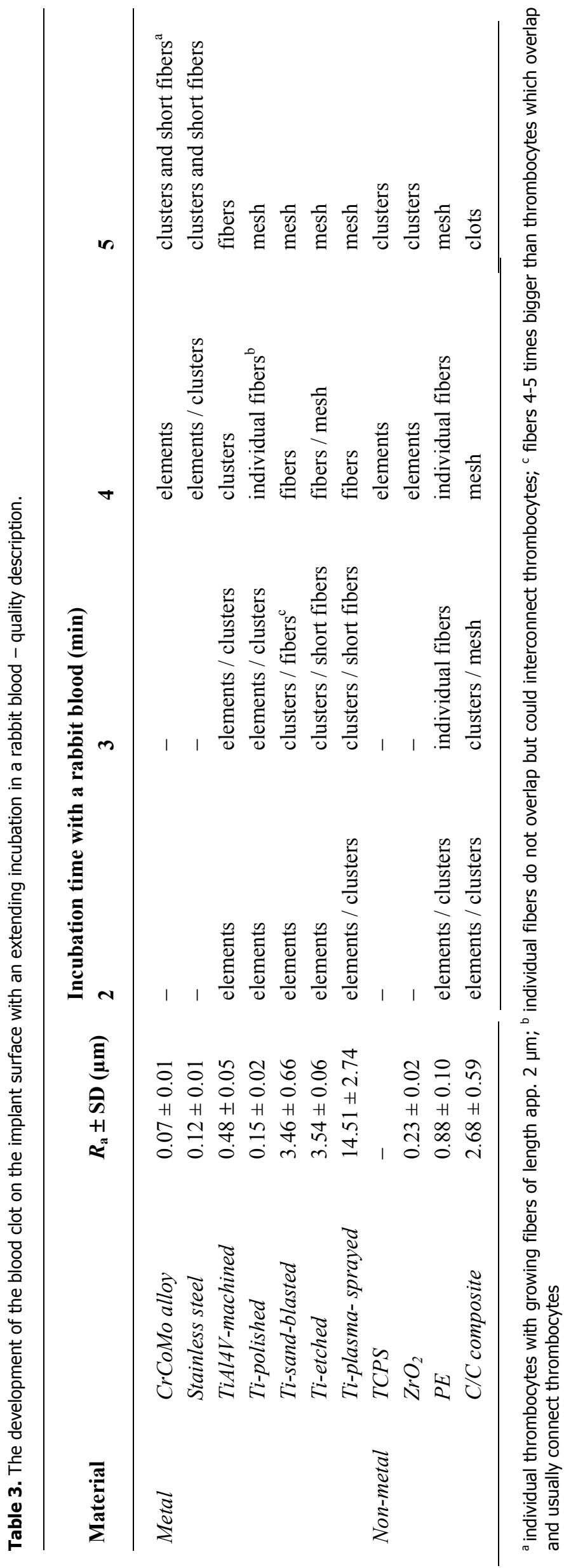


The highest quantity of all investigated parameters, except clusters, was detected for the Ti-etched surface. This difference was statistically significant at the level $\mathrm{p}=0.001$ according to KruskalWallis analysis. Moreover, a dense fibrin mesh with entrapped various blood elements was typically observed on this surface in many of scanned fields (Fig. 10c). The mesh was developed also on Ti-polished but with a statistically significant lower amount of elements and fibers than observed on Ti-etched. The Fig. 10b illustrates a frequent cluster formation with few fibers created on the Ti-polished surface.

The statistically significant differences among Ti-polished, Ti-plasma-sprayed, $\mathrm{ZrO}_{2}$ ceramics and stainless steel surfaces were mainly in the formation of fibrin fibres. The Ti-plasma-sprayed and stainless steel surfaces induced formation of higher amount of fibres than $\mathrm{ZrO}_{2}$ ceramics and Ti-polished ( $\mathrm{p}=0.05$ according Mann-Whitney test). No statistically significant differences were observed between the Ti-plasmasprayed and stainless steel surfaces as well as between the $\mathrm{ZrO}_{2}$ ceramic and Ti-polished surfaces. However, it was observed using SEM (not presented) that fibrin fibres developed on Ti-plasma-sprayed were almost 10 times longer than fibers on stainless steel.

\section{Discussion}

In this study we intended to tabularly demonstrate a main relation between surface characteristics and an early osteoblast response and the blood clot formation and thus to facilitate an orientation in a wide range of the implant materials already in a practical use. Besides Ti-based materials, materials not frequently used, such as $\mathrm{CrCoMo}$ alloy or the tested $\mathrm{C} / \mathrm{C}$ composite (Pešáková et al. 2005), were also included in to this study for better illustration of an effect of physicochemical parameters on the cell behavior. On behalf of better approaching to conditions in a real bone tissue, the human osteoblasts derived from a human connective tissue and from low passages were used for experiments. Two main parameters of an early cell response to an artificial support were studied, i.e. cell proliferation and the synthetic activity, with a respect to three general surface characteristics, i.e. the surface free energy, the surface roughness and wettability.

The tested materials were divided into three groups based on the decreasing osteoblast proliferation (Fig. 3). Generally, the osteoblast proliferation decreased with a decreasing polar component $\gamma^{p}$ of the surface free energy and with a decreasing surface roughness. In the group of the best proliferation (TCPS, Ti-plasma-sprayed, Ti-sand-blasted, Ti-etched), $\gamma, \gamma$ and $\gamma^{D}$ were not directly determined for rough Ti-based surfaces because of the impact of roughness on the contact angles. Yet if we take into account that $\gamma$ is given by the surface properties based upon the physico-chemical interactions on the atomic level, $\gamma$ obtained for the smooth Ti-polished surface may be applied with an approximation also to rough titanium surfaces. It concerns, in particular, the effect of high $\gamma^{\mathrm{P}}(15.97 \mathrm{mN} / \mathrm{m})$ on the osteoblast proliferation on the Ti-plasma-sprayed and Ti-sandblasted surfaces. In the case of the smooth control TCPS surface, we assumed that the supporting effect of the surface roughness on proliferation is compensated by high value of the polar component of the surface free energy $\left(\gamma^{\mathrm{P}}=27.06 \mathrm{mN} / \mathrm{m}\right)$. An importance of $\gamma^{\mathrm{P}}$ is also clearly demonstrated by the third group of tested materials (CrCoMo alloy, PE and C/C composite) with $\gamma^{\mathrm{P}}$ near zero (Table 2), where proliferation after four-day cultivation did not significantly exceed an initial number of cells inoculated on these surfaces.

The observed dependence of osteoblast proliferation onto commercial implant materials on $\gamma^{\mathrm{P}}$ is in accordance with data published in the literature until now. The surface energy was dominating factor in the cell adhesion strength and proliferation in the presence either absence of proteins (Schakenraad et al. 1986). The enhancement of $\gamma^{P}$ of the modified zirconia bioceramic played a significant role in the initial cell attachment, thus enhancing the cell growth (Hao et al. 2004). Interestingly, higher $\gamma^{P}$ of modified calcium phosphate surfaces caused increased osteoblast adhesion but lower protein adsorption (Dos Santos et al. 2008). The effects of $\gamma$ on the cell behavior were observed also in several long-term studies. MG63 osteoblastic cells cultured on hydroxylated high-surface-energy Ti surfaces exhibited an increased production of bone alkaline phosphatase and osteocalcin (Zhao et al. 2005). The human trabecular osteoblastic cells expressed more collagen on the highsurface-energy hydroxyapatite compared to the lowsurface-energy carbonate apatite, though the initial cell proliferation did not differ on both surfaces (Redey et al. 2000). The relatively uniform initial proliferation was observed for materials inducing the highest cell number also in our study (see Fig. 3, the first group).

The tendency to the enhanced osteoblast proliferation on rougher materials (Fig. 3) is in the 

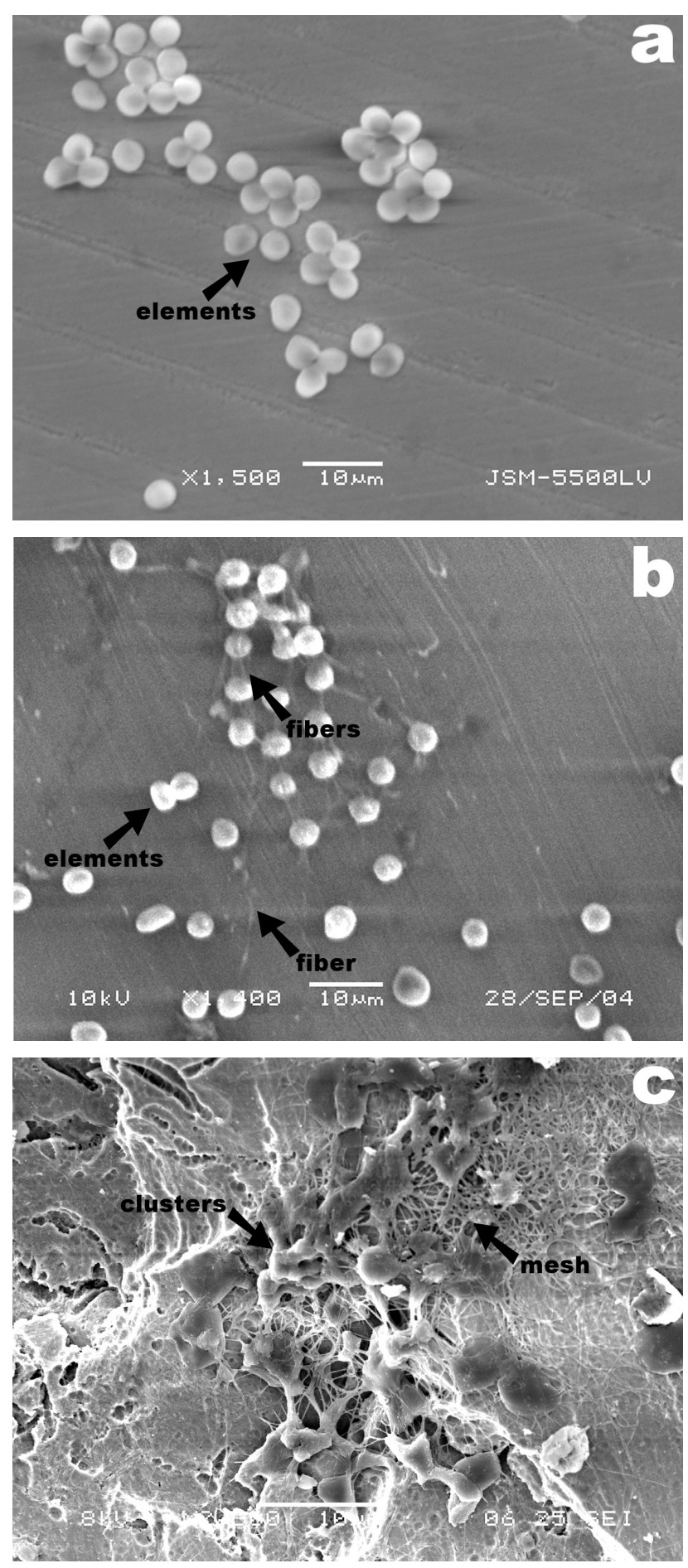

Fig. 10. SEM micrographs of samples treated with rabbit blood for 4 minutes: a) $\mathrm{ZrO}_{2}$ ceramics - round-shape elements are present, b) Ti-polished - elements and individual fibrin fibres are present, c) Ti-etched - clusters and fibrin mesh are present.

contrast to fibroblasts which preferred smooth surfaces (Pešáková et al. 2007). However, this effect is not as dramatic as it was expected and as it is often mentioned in the literature. The deepest irregularities observed on the Ti-plasma-sprayed surface (the highest value of $R_{\mathrm{z}}$, see Table 1) surely provided a totally available surface area larger than others, but a significantly higher number of cells was not found on this surface. This is probably because the cells did not utilize an overall available surface and bridge the grooves as it was observed on model smooth and microgrooved polystyrene supports (Walboomers et al. 1999). The osteoblasts cultivated on Ti materials with ultra-high roughness $(18-74 \mu \mathrm{m})$ behaved similarly to those cultivated on the coatings already used in orthopaedics (Borsari et al. 2005). The authors concluded that the roughness greater than cell dimensions does not enhance the cell response.

The surface wettability is concerned as one of the main factors reflecting an extent of cell adhesion onto the surface (Park et al. 2001, Fujisato et al. 1996). According to the literature, hydrophilic metal as well as non-metal surfaces are generally favourable for the short-term cell adhesion and proliferation for various cell types such as erythrocytes (Absolom et al. 1985), lymphocytes (Groth et al. 1994) or human epithelial cells (Allen et al. 2006). The maximum adhesion and growth of hepatoma cells, osteoblasts, bovine aortic endothelial cells and fibroblasts on smooth poly(lactide-glycolide) based films appeared at around water contact angles of 53 to $55^{\circ}$ (Khang et al. 2002) and these data could serve as an illustration of an extend of the appropriated surface wettability.

However, the contact angles usually observed for Ti-based surfaces vary between 70 to $90^{\circ}$ based on the source of the Ti material. Therefore, a big interest is focused on a development of surface treatments leading to more hydrophilic surfaces recently. For example, the treatment of Ti6Al4V or stainless steel by the HPDL laser provided a decrease in $\theta$ by $10^{\circ}$ and an increase in $\gamma^{p}$ and thus the favourable response of human fetal osteoblast cells (Hao et al. 2005, Hao et al. 2005). The improved cell activity was observed on nanostructured Ti-based materials with wettability of $62^{\circ}$ (Faghihi et al. 2007) or on sol-gel-modified Ti6A14V substrates with an extremely high wettability $\left(\theta=18^{\circ}\right), \gamma^{P}=30 \pm 3 \mathrm{mN} / \mathrm{m}$ and roughness of $R_{\mathrm{a}}=0.1 \mu \mathrm{m}$ (Advincula et al. 2006). The enhanced mineralization was detected on model hydrophilic flat surfaces relative to hydrophobic ones (Lim et al. 2008). Nevertheless, it is important to point out, that all surfaces discussed above are smooth surfaces with the surface roughness not exceeding $0.6 \mu \mathrm{m}$, in comparison with rougher cementless direct bone bonding implants used in the clinic.

Based on the obtained results, wettability seems to have a minor effect on the osteoblast proliferation in 
Table 4. The character of the blood clot after 4 minute of the incubation in a rabbit blood*.

\begin{tabular}{lllll}
\hline Surface & $\begin{array}{l}\text { Elements } \\
\left(\mathbf{n u m b e r} / \mathbf{m m}^{2}\right)\end{array}$ & $\begin{array}{l}\text { Clusters } \\
\left(\mathbf{n u m b e r} / \mathbf{m m}^{\mathbf{2}}\right)\end{array}$ & $\begin{array}{l}\text { Fibers } \\
\left(\mathbf{n u m b e r} / \mathbf{m m}^{\mathbf{2}}\right)\end{array}$ & $\begin{array}{l}\text { Mesh } \\
\text { (surface coverage \%) }\end{array}$ \\
\hline Ti-polished & $2731 \pm 1617$ & $456 \pm 181$ & $335 \pm 148$ & $20 \pm 12$ \\
Ti-etched & $4187 \pm 2116$ & $127 \pm 56$ & $2448 \pm 1531$ & $22 \pm 14$ \\
Ti-plasma-sprayed & $3169 \pm 1303$ & $136 \pm 59$ & $1183 \pm 638$ & $2 \pm 1$ \\
$\mathrm{ZrO}_{2}$ & $3111 \pm 1023$ & $288 \pm 193$ & $81 \pm 29$ & 0 \\
Stainless steel & $2906 \pm 1447$ & $307 \pm 164$ & $1418 \pm 909$ & 0 \\
\hline
\end{tabular}

* Statistic comments on results are mentioned in the text in the paragraph "Blood clot formation analysis", data are presented as mean \pm S.D.

our study. The group of materials with the highest proliferation includes the moderately hydrophilic TCPS and Ti-etched surfaces as well as the hydrophobic Tisand-blasted and the highly hydrophobic Ti-plasmasprayed surfaces (Figs 2, 3). This is also in contrast to the fibroblast cultivation where the cells proliferated best on the moderately hydrophilic Ti-polished and $\mathrm{ZrO}_{2}$ ceramic surfaces with $\theta_{\mathrm{A}}<70^{\circ}$ (Pešáková et al. 2007). Thus, wettability seems to be an important factor significantly augmenting the osteoblast activity especially on smooth surfaces. However, the surface roughness, though not optimal for proliferation of cells, is highly required from a biomechanical point of view for a long-term successful function of the bone-embedded implants. According to clinical experiences, the surface roughness leads to better distribution of a loading force onto the bone bed and limits the microcrack formation (Wiskott et al. 1999).

The following studied parameter of an early cell response to an artificial support was the synthetic activity of osteoblasts. In the course of the synthetic phase of the cellular cycle, cells synthesize not only substances necessary for the cell multiplication, but also substances which affect and determine the future existence of the cells. The bone alkaline phosphatase (BAP) is a biochemical marker of the osteoblast phenotype in the stage of early differentiation, and hence also of bone formation and general osteoblast activity. This protein is also involved in the bone mineralisation process (Piattelli et al. 1996). The multi-potent growth factor TGF- $\beta$ has regulating effects on migration, proliferation and differentiation of cells, stimulates the extracellular matrix protein expression (e.g. the synthesis of collagen and fibronectin) and also restricts the synthesis of proteases and increases production of their inhibitors (Shaama 2005). TGF- $\beta$ is also one of the most potent immunoregulatory molecules known. Studies using a simple TGF- $\beta$ adsorption indicate that delivery of TGF- $\beta$ to the tissue-implant interface can improve bone formation in the periprosthetic gap and can enhance bone ingrowth into porous coatings (Kloen 1997). The next markers of the osteoblast activity are matrix metalloproteinases (MMP), which catalyze degradation of extracellular matrix proteins and thereby play an important role in many physiological and pathological processes also including tissue remodelling, wound healing or inflammation (Pap et al. 1999).

There was an obvious tendency towards an increased expression of BAP, TGF- $\beta$ and MMP-1 with decreasing proliferation in our study. The increased expression of osteoblastic phenotype markers with the reduced cell proliferation was also found in in vitro studies using MG63 osteoblast-like cells (Borsari et al. 2005, Boyan et al. 2002). It is generally known that, in order to survive, most of the cells need to adhere. Therefore, the contact between individual cells or between the cell and the surface through a specific adsorption is highly required for a successful cell growth in vitro. In the present work, the increased synthetic production observed on CrCoMo alloy and PE is explained as follow: with a low number of the proliferating osteoblasts, the cells try to compensate the deficit in their count by an increased synthetic activity aimed at, at the close, higher expression of extracellular matrix proteins. However, if the surface is not attractive enough for adhesion and proliferation of cells $(\mathrm{C} / \mathrm{C}$ composite here), it can be assumed that adhered cells are not stimulated to exhibit the synthetic activity. In the group with the highest proliferation in our study, the Ti-etched surface initiated the highest production of osteoblast activity markers.

The expression of the tumor necrosis factor (TNF- $\alpha$ ) as a main mediator of the inflammatory response was studied as well. The function of TNF- $\alpha$ should be 
viewed in three ways: as a stimulus for acute inflammation, as a chronic contributor to autoimmune disorders and/or as a local regulator of bone cell function involved in skeletal catabolic processes in pathophysiology of osteoporosis (Nanes 2003, Rifas 1999). Interestingly, it seems that higher TNF- $\alpha$ expression depends primarily on the material origin, namely Ti-based surfaces, in our study. To our knowledge, this phenomenon has not been mentioned in the literature until now. Among the materials involved in the group with the highest proliferation, the expression of both TNF- $\alpha$ and IL- 8 was the lowest on the Ti-etched surface where the chemical composition of the titanium surface has been altered by etching.

The way how the implant surface induces the formation of the blood clot is a very important characteristic of the material, because the clotting blood is the first connection site of the implant and a living host tissue (Park et al. 2001). One of the triggers activating coagulation is a damage of blood vessels due to surgery. The contact with the implant surface is an additional trigger which starts coagulation cascade and the attractiveness of the implant surface to blood could play a very important role in speed of osteointegration as well as in a sealing of wound. Apparently, the surface roughness seems to be the main factor regulating the blood coagulation in our study (Table 3 ). This dominating effect is demonstrated also by relatively fast formation of the blood clot on $\mathrm{C} / \mathrm{C}$ composite, which is known, in contrary, to be an extremely thromboresistant material. The used $\mathrm{C} / \mathrm{C}$ composite material unfortunately exhibited big irregularities on the surface (Fig. 1i) as a result of the final surface treatment. The slowest clot formation was detected on the materials with low surface roughness (TCPS, $\mathrm{ZrO}_{2}, \mathrm{CrCoMo}$, stainless steel, Table 3) and with no evident effect of wettability or $\gamma^{\mathrm{P}}$. On the other hand, the mesh was formed on the smooth Ti-polished surface. Thus we can assume that the particular surface composition/properties, which are not reflected by wettability or $\gamma^{p}$ in our study, should be also a trigger of coagulation in the case of smooth surfaces. For example, platelets can also be activated by smooth negatively or positively charged surfaces (Lee et al. 1998).

Among the surfaces with higher proliferation (Fig. 3, group 1 and 2, see Part Proliferation of osteoblasts on implant materials), the mesh was formed only on all Tibased surfaces. The highest quantity of all investigated parameters (blood elements, clusters of aggregated elements, fibrin fibres) was detected for the Ti-etched surface (Table 4). A lower number of formed clusters probably resulted from more homogeneous adhesion of platelets on this surface potentiated by fast platelet activation. This led to very early formation of the fibrin fibres and, consequently, to the development of the mesh. Differences in the fibrin fibre category (Table 4) observed among Ti-polished, Ti-plasma-sprayed, $\mathrm{ZrO}_{2}$ ceramics and stainless steel could be explained by combination of the surface and bulk material properties. A lower amount of fibres on the Ti-plasma-sprayed surface could be caused by high surface roughness where formed short fibers were not long enough to bridge the deep irregularities of the surface and thus retarded formation of longer fibrin fibers. Further, we suppose that low amount of fibres developed onto Tipolished could result from formation of the dense mesh especially around the clusters of aggregated platelets. The stainless steel induced higher formation of the fibrin fibres probably due to material properties whereas $\mathrm{ZrO}_{2}$ ceramics is an inert material with adhered but not activated roundshape platelets on the surface (Fig. 10a).

From the practical point of view, the study was aimed at looking for the commercially available implant material with the fastest healing. The shortening of healing is an important factor not only from economic aspects (treatment time and costs in the hospital), but primarily from a viewpoint of the patient comfort. Concerning e.g. dental applications, the immediate loading concept requires the quickest healing in first few days to stabilize the implant and makes a shield against micromotions. The blood clot can be considered as a natural scaffold augmenting the cell migration and seeding on the bone-implant interface. Therefore, not only a satisfactory high osteoblast proliferation and synthetic activity related to specific surface characteristics should be main factors for selection of an appropriate implant material. However, it is not completely clear from a clinic practice, which of these factors is more important for fast healing. Therefore it is desired to search for an optimal intersection point for high osteoblast proliferation, low fibroblast proliferation and fast blood clot formation.

Beyond all convenience of the rough Ti-plasmasprayed surface, which is characterized especially by the highest proliferation in this study, problems arising during implantation due to bigger amount of bone wear debris evoking immune response cannot be omitted. Also slower blood clot formation makes this surface treatment not optimal. Further, in contrast to our expectation, $\mathrm{ZrO}_{2}$ ceramics did not belong to the most suitable candidates, 
neither in term of proliferation and the synthetic activity nor in term of a sufficiently fast blood clot formation. Nevertheless, from the point of view of an appearance of allergy to titanium materials and because of low wear debris, $\mathrm{ZrO}_{2}$ ceramics is still the promising implant material. The Ti-polished surface represents an advantageous material in term of the blood clot formation but due to its low surface roughness and the moderate wettability is also well colonized by fibroblasts (Pešáková et al. 2007) which are undesirable cells on the boneimplant interface. The Ti-etched surface seems to be the most convenient compromise in term of the osteoblast proliferation and the synthetic activity and the fast blood clot formation due to the $\mathrm{TiO}_{2}$ structure yielding a high $\gamma^{\mathrm{P}}$ and the etching treatment leading to the convenient wettability, the surface charge and the surface roughness.

\section{Conclusions}

The wide range of commercially available bone implant materials was classified by proliferation and the synthetic activity of osteoblasts and the blood clot formation with respect to the surface properties such as roughness, the surface free energy and/or wettability. Based on proliferation, tested materials were divided into 3 groups. The results indicate that the important factor supporting the osteoblast proliferation activity is the polar part of SFE $\left(\gamma^{\mathrm{p}}\right)$ supported by the surface roughness, here exceeding $3.5 \mu \mathrm{m}$ ( $1^{\text {st }}$ group). In the $2^{\text {nd }}$ group of materials (smooth surfaces), the impact of roughness to proliferation is compensated by higher $\gamma^{\mathrm{p}}\left(\gamma^{\mathrm{p}}>8 \mathrm{mN} / \mathrm{m}\right)$. Finally, the lowest osteoblast proliferation (3rd group) was detected on materials with the almost zero $\gamma^{\mathrm{p}}$ (CrCoMo alloy, PE, C/C composite).
The markers of osteogenesis (BAP, TGF- $\beta$ ) were always higher on tested surfaces than on the TCPS control and were inversely related to the cell number independently on the surface roughness. A dramatically higher expression was detected on surfaces with low proliferation and with $\gamma^{\mathrm{p}}$ nearing zero, what reflected inconvenient conditions for the cell adhesion. The production of inflammatory mediators (TNF- $\alpha$, Il-8) is distinctively higher on all surfaces in comparison to TCPS and there is a tendency to an increased TNF- $\alpha$ production especially on the Ti-based surfaces with no respect to the surface roughness.

The analysis of the blood clot formation showed the rapid coagulation on rough titanium surfaces whereas materials with smooth surfaces agglutinated blood more slowly. No evident effect of wettability or the surface free energy on coagulation was observed.

Finally, the titanium surface modified with the etching treatment seems to be the most suitable candidate for healing into the bone tissue among tested materials due to high osteoblast proliferation, the highest production of osteogenesis markers, a low production of inflammatory cytokines and due to the most intensive formation of the blood clot.

\section{Conflict of Interest}

There is no conflict of interest.

\section{Acknowledgements}

This work was supported by Ministry of Healthy project No. 00023728, Centrum for Cell Therapy and Tissue Repair, MSMT:1M0021620803 and Ministry of Education, Youth and Sports DP No. 14/15.

\section{References}

ABSOLOM DR, ZINGG W, THOMSON C, POLICOVA Z, VAN OSS CJ, NEUMAN AW: Erythrocyte adhesion to polymer surfaces. J Colloid Interface Sci 104: 51-59, 1985.

ADVINCULA MC, RATHEMULLA G, ADVINCULA RC, ADA ET, LAMONS JE, BELLIS SL: Osteoblast adhesion and matrix mineralization on sol-gel-derived titanium oxide. Biomaterials 27: 2201-2212, 2006.

ALLEN LT, TOSETTO M., MILLER IS, O'CONNOR DP, PENNEY SC, LYNCH I: Surface-induced changes in protein adsorption and implications for cellular phenotypic responses to surface interaction. Biomaterials 27: 3096-3108, 2006.

ANDRADE JD, SMITH LM, GREGONIS DE: The contact angle and interface energetics. In: Surface and Interfacial Aspects of Biomedical Polymers, Vol. 1 Surface Chemistry and Physics. ANDRADE JD (ed), Plenum Press, New York, 1985, pp 249-290.

BANCROFT GN, MIKOS AG: Bone tissue engineering by cell transplantation. Tissue Engineering for Therapeutic Use 5. Int. Congress Series. Vol. 1222, 2001, pp 151-163. 
BORSARI V, GIAVARESI G, FINI M, TORRICELLI P, TSCHON M, CHIESA R, CHIUSOLI L, SALITO A, VOLPERT A, GIARDINO R: Comparative in vitro study on a ultra-high roughness and dense titanium coating. Biomaterials 26: 4948-4955, 2005.

BOYAN BD, BONEWALD LF, PASCHALIS EP, LOHMANN CH, ROSSER J, COCHRAN DL, DEAN DD, SCHWARTZ Z, BOSKAY AL: Osteoblast-mediated mineral deposition in culture is dependent on surface microtopography. Calcif Tissue Int 71: 519-526, 2002.

DEL FABBRO M, ROSANO G, TASCHIERI S: Implant survival rates after maxillary sinus augmentation. Eur J Oral Sci 116: 497-506, 2008.

DOS SANTOS EA, FARINA M, SOARES GA, ANSELME K: Surface energy of hydroxyapatite and beta-tricalcium phosphate ceramics driving serum protein adsorption and osteoblast adhesion. J Mater Sci: Mater Med 19: $2307-$ 2316, 2008.

EASTLUND T: Infectious disease transmission through cell, tissue, and organ transplantation: reducing the risk through donor selection. Cell Transplant 5: 455-477, 1995.

FAGHIHI S, AZARI F, ZHILYAEV AP, SZPUNAR JA, VALI H, TABRIZIAN M: Cellular and molecular interactions between MC3T3-E1 pre-osteoblasts and nanostructured titanium produced by high-pressure torsion. Biomaterials 28: 3887-3895, 2007.

FRANCHI M, ORSINI E, TRIRE A, QUARANTA M, MARTINI D, PICCARI GG, RUGGERI A, OTTANI V: Osteogenesis and morphology of the peri- implant bone facing dental implants. Sci World J 14: 1083-1095, 2004.

FRITZ EA, GLANT TT, VERMES C, JACOBS JJ, ROEBUCK KA: Titanium particles induce the immediate early stress responsive chemokines IL-8 and MCP-1 in osteoblasts. J Orthop Res 20: 490-498, 2002.

FUJISATO T, SAJIKI T, LIU Q, IKADAY: Effect of basic fibroblast growth factor on cartilage regeneration in chondrocyte-seeded collagen sponge scaffold. Biomaterials 17: 155-162, 1996.

GROTH TH, ALTANKOV G, KLOSH K: Adhesion of human peripheral blood lymphocytes is dependent on surface wettability and protein preadsorption. Biomaterials 15: 423-428, 1994.

HAO L, LAWRENCE L, LI L: The wettability modification of bio-grade stainless steel in contact with simulated physiological liquids by the means of laser irradiation. Appl Surface Sci 247: 453-457, 2005.

HAO L, LAWRENCE L, PHUA YF, CHIAN KS, LIM GC, ZHENG HY: Enhanced human osteoblast cell adhesion and proliferation on $316 \mathrm{LS}$ stainless steel by means of $\mathrm{CO}_{2}$ laser surface treatment. J Biomed Mater Res B - Applied Biomaterials 73B: 148-156, 2005.

HAO L, LAWRENCE L, CHIAN KS: Effects of $\mathrm{CO}_{2}$ laser irradiation on the surface properties of magnesia-partially stabilised zirconia (MgO-PSZ) bioceramic and the subsequent improvements in human osteoblast cell adhesion. $J$ Biomater Appl 19: 81-105, 2004.

JONES MI, MCCOLL IR, GRANT DM, PARKER KG, PARKERT L: Haemocompatibility of DLC and TiC-TiN interlayers on titanium. Diamond Related Materials 8: 457-462, 1999.

KHANG G, CHOEE HJ, RHEE MH, LEE B: Interaction of different types of cells on physicochemically treated poly(Llactide-co-glycolide) surfaces. J Appl Polym Sci 85: 1253-1262, 2002.

KLOEN P: Expression of transforming growth factor-beta (TGF-beta) isoforms in osteosarcomas - TGF-beta 3 is related to disease progression. Cancer 12: 2230-2239, 1997.

LAUGHTON C: Quantification of attached cells in microtiter plates based on Coomassie Brilliant blue G-250. Staining of total cellular protein. Anal Biochemistry 140: 417-423, 1984.

LEE JH, KHANG G, LEE JW, LEE HB: Platelet adhesion onto chargeable functional group gradient surfaces, $J$ Biomed Mater Res 40: 180-186, 1998.

LIM JY, SHAUGHNESSY MC, ZHOU Z, NOH H, VOGLER EA, DONAHUE HJ: Surface energy effects on osteoblast spatial growth and mineralization. Biomaterials 29: 1776-1784, 2008.

MARCHETTI C, PIERI F, CORINALDESI G, DEGIDI M: A long-term retrospective study of two different implant surfaces placed after reconstruction of the severely resorbed maxilla using Le Fort I osteotomy and interpositional bone grafting. Int J Oral Maxillofac Implants 23: 911-928, 2008.

MOSMANN T: Rapid colorimetric assay for cell proliferation and survival application to proliferation and cytotoxicity assays. J Immun Methods 65: 55-61, 1983.

NANES MS: Tumor necrosis factor - a: molecular and cellular mechanisms in skeletal pathology. Gene 321: 1-15, 2003. 
OKUMURA A, GOTO M, GOTO T, YOSHINARI M, MASUKO S, KATSUKI T, TANAKA T: Substrate affects the initial attachment and subsequent behavior of human osteoblastic cells (Saos-2). Biomaterials 22: 2263-2271, 2001.

OWENS DK, WENDT RC: Estimation of the surface free energy of polymers. J Appl Polym Sci 13: 1741-1747, 1969.

PAP T, PAP G, HUMMEL KM, FRANZ JK, JEISY E, SAINSBURY I, GAY RE, BILLINGHAM M, NEUMANN W, GAY S: Membrane-type-1 matrix metalloproteinase is abundantly expressed in fibroblasts and osteoclasts at the bone-implant interface of aseptically loosened joint arthroplasties in situ. J Rheumatol 26: 166-169, 1999.

PARK JY, GEMMELL CH, DAVIES JE: Platelet interactions with titanium: modulation of platelet activity by surface topography. Biomaterials 22: 2671-2682, 2001.

PEGUEROLES M, GIL FJ, PLANELL JA, APARICIO C: The influence of blasting and sterilization on static and timerelated wettability and surface-energy properties of titanium surfaces. Surface \& Coatings Technology 202: 34703479, 2008.

PEŠÁKOVÁ V, KLÉZL Z, BALÍK K, ADAM M: Biomechanical and biological properties of the implant material carbon-carbon composite covered with pyrolytic carbon. J Mater Sci: Mater Med 11: 793-798, 2000.

PEŠÁKOVÁ V, KUBIES D, HULEJOVÁ H, HIMMLOVÁ L: The influence of implant surface properties on cell adhesion and proliferation. J Mater Sci: Mater Med 18: 465-473, 2007.

PEŠÁKOVÁ V, SMETANA K, SOCHOR M, HULEJOVÁ H, BALÍK K: Biological properties of the intervertebral cages made of titanium containing a carbon-carbon composite covered with different polymers. J Mater Sci: Mater Med 16: 143-148, 2005.

PIATTELLI A, SCARANO A, CORIGLIANO M, PIATTELLI M: Effects of alkaline phosphatase on bone healing around plasma-sprayed titanium implants: a pilot study in rabbits. Biomaterials 17: 1443-1449, 1996.

PONSONNET L, REYBIER K, JAFFREZIE N, COMTE V, LAGNEAU C, LISSAC M, MARTELET C: Relationship between surface properties (roughness, wettability) of titanium and titanium alloys and cell behaviour. Materials Science and Engineering C-Biomimetic and Supramolecular Systems 23: 551-560, 2003.

REDEY SA, NARDIN M., BERNACHE-ASSOLANT D, REY C., DELANNOY P, SEDE L: Behavior of human osteoblastic cells on stoichiometric hydroxyapatite and type A carbonate apatite: role of surface energy. J Biomed Mater Res 50: 353-364, 2000.

RIFAS L: Bone and cytokines: beyond IL-1, IL-6 and TNF $\alpha$. Calcif Tissue Int 64: 1-7, 1999.

SHAAMA FA: An in vitro comparison of implant materials cell attachment, cytokine and osteocalcin production. West Indian Med J 54: 250-256, 2005.

SCHAKENRAAD JM, BUSSCHER HJ, WILDEVUUR CRH, ARENDS J: The influence of substratum surface free energy on growth and spreading of human fibroblasts in the presence and absence of serum proteins. $J$ Biomed Mater Res 20: 773-784, 1986.

SCHWEIKL H, MULLER R, ENGLERT C, HILLER KA, KUJAT R, NERLICH M, SCHMALZ G: Proliferation of osteoblasts and fibroblasts on model surfaces of varying roughness and surface chemistry. J Mater Sci: Mater Med 18: 1895-1905, 2007.

SINHA RK, TUAN RS: Regulation of human osteoblast integrin expression by orthopedic implant materials. Bone 18: 451-457, 1996.

STEINBERG AD, WILLEY R, DRUMMOND JL: In-vivo comparisons of clot formation on titanium and hydroxyapatitecoated titanium J Periodontol 63: 990-994, 1992.

WALBOOMERS XF, MONAGHAN W, CURTIS ASG, JANSEN JA: Attachment of fibroblasts on smooth and microgrooved polystyrene. J Biomed Mater Res 46: 212-220, 1999.

WEBB K, HLADY V, TRESCO PA: Relationships among cell attachment, spreading, cytoskeletal organization, and migration rate for anchorage-dependent cells on model surfaces. J Biomed Mater Res 49: 362-372, 2000.

WISKOTT HW, BELSER UC: Lack of integration of smooth titanium surfaces: a working hypothesis based on strains generated in the surrounding bone. Clin Oral Implants Res 10: 429-444, 1999.

ZHAO G, SCHWARTZ Z, WIELAND M, RUPP F, GEIS-GERSTORFER J, COCHRAN DL, BOYAN BD: High surface energy enhances cell response to titanium substrate microstructure. J Biomed Mater Res 74: 49-58, 2005. 